\title{
The transcriptome of Populus in elevated $\mathrm{CO}_{2}$ reveals increased anthocyanin biosynthesis during delayed autumnal senescence
}

\author{
M. J. Tallis ${ }^{1}$, Y. Lin $^{1}$, A. Rogers ${ }^{2,3}$, J. Zhang ${ }^{1,4}$, N. R. Street ${ }^{1}$, F. Miglietta ${ }^{5}$, D. F. Karnosky ${ }^{6}$, P. De Angelis ${ }^{7}$, \\ C. Calfapietra ${ }^{7}$ and G. Taylor ${ }^{1}$ \\ ${ }^{1}$ School of Biological Science, Bassett Crescent East, University of Southampton, Southampton SO16 7PX, UK; ${ }^{2}$ Environmental Sciences Department, \\ Brookhaven National Laboratory, Upton, NY 11973, USA; ${ }^{3}$ Department of Crop Sciences, University of Illinois at Urbana, Champaign, Urbana, IL \\ 61801, USA; ${ }^{4}$ College of Life Sciences, Peking University, Beijing 100871, China; ${ }^{5}$ Institute of Biometeorology-CNR, Via Caproni, 850145 Firenze, Italy; \\ ${ }^{6}$ School of Forest Resources \& Environmental Science, Michigan Technological University, 1400 Townsend Drive, Houghton, MI 49931-1295, USA; \\ ${ }^{7}$ Department of Forest Environment and Resources (DISAFRI), University of Tuscia, Via S. Camillo De Lellis, 01100 Viterbo, Italy
}

Author for correspondence:

Gail Taylor

Tel: +44 (0)2380592335

Email: g.taylor@soton.ac.uk

Received: 22 September 2009

Accepted: 8 December 2009

New Phytologist (2010) 186: 415-428

doi: 10.1111/j.1469-8137.2010.03184.x

Key words: anthocyanin biosynthesis, autumnal senescence, cDNA microarray, elevated $\mathrm{CO}_{2}$, LDOX, Populus.

\section{Summary}

- The delay in autumnal senescence that has occurred in recent decades has been linked to rising temperatures. Here, we suggest that increasing atmospheric $\mathrm{CO}_{2}$ may partly account for delayed autumnal senescence and for the first time, through transcriptome analysis, identify gene expression changes associated with this delay.

- Using a plantation of Populus $\times$ euramericana grown in elevated $\left[\mathrm{CO}_{2}\right]$ $\left(e\left[\mathrm{CO}_{2}\right]\right)$ with free-air $\mathrm{CO}_{2}$ enrichment (FACE) technology, we investigated the molecular and biochemical basis of this response. A Populus CDNA microarray was used to identify genes representing multiple biochemical pathways influenced by $\mathrm{e}\left[\mathrm{CO}_{2}\right]$ during senescence. Gene expression changes were confirmed through real-time quantitative $P C R$, and leaf biochemical assays.

- Pathways for secondary metabolism and glycolysis were significantly up-regulated by e[ $\left.\mathrm{CO}_{2}\right]$ during senescence, in particular, those related to anthocyanin biosynthesis. Expressed sequence tags (ESTs) representing the two most significantly up-regulated transcripts in $\mathrm{e}\left[\mathrm{CO}_{2}\right], \mathrm{LDOX}$ (leucoanthocyanidin dioxgenase) and

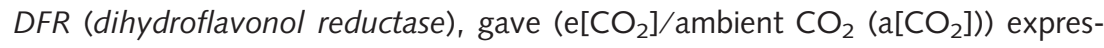
sion ratios of 39.6 and 19.3 , respectively.

- We showed that in e[ $\left[\mathrm{CO}_{2}\right]$ there was increased autumnal leaf sugar accumulation and up-regulation of genes determining anthocyanin biosynthesis which, we propose, prolongs leaf longevity during natural autumnal senescence.

\section{Introduction}

Phenological records suggest that recent global warming has resulted in longer growing seasons. An analysis of over 1700 species showed significant shifts in plant phenology

Dedication: this manuscript is dedicated to David F. Karnosky, who died in 2008, but provided the initial inspiration following our serendipitous observations in the USA and Italy that leaves stayed green for longer in high $\mathrm{CO}_{2}$.
(Parmesan \& Yohe, 2003), including extension of the growing season (Myneni et al., 1997; Menzel \& Fabian, 1999; Zhou et al., 2001; Menzel et al., 2006), which has been attributed to rising air temperature (Menzel \& Fabian, 1999). On average over the past $35 \mathrm{yr}$ autumnal senescence has been delayed across Europe by $1.3 \mathrm{~d}$ per decade (Menzel et al., 2006). However, while a strong correlation exists between atmospheric warming and an earlier spring phenophase, the correlation between warming and a later on-set of the autumn phenophase is very weak (Menzel 
et al., 2006). Understanding this process is important, as changing phenology can alter biogeochemical cycling and albedo, both feeding back on climate change (Peñuelas et al., 2009). For example, an extended autumn has been reported to increase carbon storage in the boreal zone of northern latitude forests (Lucht et al., 2002) and in the aspen boreal forests of North America (Chen et al., 1999). It also represents a potential mechanism for adaptation to a changing climate; understanding the genetic and genomic basis of such changes is pertinent to understanding evolutionary mechanisms and, in turn, how forests may be managed and conserved in future.

Over the time period of the Menzel et al. (2006) study (1971-2000), atmospheric carbon dioxide has increased by $44 \mu \mathrm{mol} \mathrm{mol}^{-1}(+13.5 \%)$. We have previously shown that elevated atmospheric $\mathrm{CO}_{2}\left(\mathrm{e}\left[\mathrm{CO}_{2}\right]\right)$ delays autumnal senescence in a forest canopy exposed for 6 yr to e $\left[\mathrm{CO}_{2}\right]$ under free air $\mathrm{CO}_{2}$ exposure (FACE) (Taylor et al., 2008). At the canopy level, the decline in greenness measured using the normalized difference vegetation index (NDVI) and leaf area index (LAI) were both significantly reduced by e $\left[\mathrm{CO}_{2}\right]$. Also delayed was the decline in leaf chlorophyll, indicating delayed senescence in these trees (Taylor et al., 2008). However, these finding are controversial, as rising $\left[\mathrm{CO}_{2}\right]$ has been shown to shorten (Sigurdsson, 2001), extend (Li et al., 2000; Rae et al., 2006; Taylor et al., 2008) or have no effect (Herrick \& Thomas, 2003) on forest senescence.

Natural autumnal senescence is regulated by day length, temperature, light, nitrogen, water supply, plant carbonnitrogen and source-sink balance (Wingler et al., 2006), the timing of which can be regarded as the result of a tradeoff between the conflicting requirements for optimizing the nitrogen and carbon status of the plant (Keskitalo et al., 2005). The strength of the plant's sink for photosynthate can positively influence photosynthetic responses to e $\left[\mathrm{CO}_{2}\right]$ (Bryant et al., 1998; Ainsworth et al., 2004) and also reduce the rate of senescence (Wingler et al., 2004; Kaschuk et al., 2009). Recent studies using girdled sugar maple trees have shown that sugar accumulation in leaves resulted in the formation of anthocyanins (Murakami et al., 2008), and leaves with increased anthocyanin content were associated with a delayed senescence (Schaberg et al., 2008). In poplar, overexpressing an Arabidopsis sucrose phosphate synthase gene resulted in increased leaf sucrose content between August and throughout senescence, which was associated with a delayed senescence (Park et al., 2009). These data indicate the complex interactions between the plants' developmental state, source-sink balance and rate of senescence. Nevertheless, the initiation and a sequence of events during senescence is well conserved. The stimulus for autumnal senescence in Populus is a shortening of the photoperiod initiating bud-set, at least for high-latitude trees (Olsen et al., 1997; Keskitalo et al., 2005; Böhlenius et al., 2006; Fracheboud et al., 2009), which is considered an adaptive trait related to plant fitness (Ingvarsson et al., 2006). Following this, a well characterized sequence of cellular events has been reported (Keskitalo et al., 2005), from chloroplast breakdown, carotenoid and soluble sugar loss to anthocyanin production, a massive $80 \%$ nitrogen remobilization and leaf abscission. During this process in poplar, 166 genes were classed as 'most up-regulated', revealing a shift from gene expression associated with anabolism to that of catabolism and an increased role of the mitochondria for energy generation as photosynthesis breaks down (Andersson et al., 2004).

The aim of this research was to understand how exposure to increased atmospheric $\mathrm{CO}_{2}$ disrupts the process of autumnal senescence and to identify key changes in metabolism and gene expression associated with delayed senescence. We conducted our investigation at the POP/EUROFACE (free air $\mathrm{CO}_{2}$ enrichment) experiment (Miglietta et al., 2001) where trees had been grown for $6 \mathrm{yr}$, from planting to canopy closure, in a fully open-air environment at either ambient $\mathrm{CO}_{2}\left(\mathrm{a}\left[\mathrm{CO}_{2}\right]\right)$ or $\mathrm{e}\left[\mathrm{CO}_{2}\right]\left(550 \mu \mathrm{mol} \mathrm{mol}^{-1}\right)$. Conducting this study at a FACE site allowed us to eliminate the potentially confounding problems of sink, nitrogen and water limitation that are common in experiments using other $\mathrm{CO}_{2}$ fumigation techniques (McLeod \& Long, 1999) and are known to influence the rate of senescence. The highly productive, fast-growing trees reported to be nonresource-limited (Liberloo et al., 2009) at the POP/ EUROFACE experiment provided the ideal model system in which to investigate the changes in natural autumnal senescence of a forest canopy growing in $\mathrm{e}\left[\mathrm{CO}_{2}\right]$. Furthermore, Populus is now recognized as a model tree genus (Taylor, 2002; Tuskan et al., 2006; Jansson \& Douglas, 2007) enabling genomic resources to be deployed to answer questions of ecological and evolutionary significance on plant response and adaptation to climate change.

\section{Materials and Methods}

\section{The POP/EUROFACE site}

The POPFACE experiment (9 ha) was situated on a nutrient-rich, clay soil in Tuscania, Italy $\left(42^{\circ} 22^{\prime} \mathrm{N}, 11^{\circ} 48^{\prime} \mathrm{E}\right.$; altitude $150 \mathrm{~m}$ asl; http://www.unitus.it/euroface). Three species of Populus (P. alba L. (clone 2AS-11), P. nigra L. (clone Jean Pourtet) and $P . \times$ euramericana (Dode) Guinier (clone I-214)) were grown in the experiment within six experimental plots assigned equally between two treatments of $\left[\mathrm{CO}_{2}\right]$ (a control of ambient $\mathrm{CO}_{2}, \mathrm{a}\left[\mathrm{CO}_{2}\right]$ and elevated $\mathrm{CO}_{2} \mathrm{e}\left[\mathrm{CO}_{2}\right]$ of $550 \mu \mathrm{mol} \mathrm{mol}^{-1}$ ), as described previously (Miglietta et al., 2001; Scarascia-Mugnozza et al., 2006). During the period of this study, trees had been planted for $6 \mathrm{yr}$, coppiced after $3 \mathrm{yr}$ and exhibited a closed canopy. Canopy characterization and climatic data during this study have been described in detail in Taylor et al. (2008) and 
only the ambient nitrogen subplots were used in this study, the same treatments as in Taylor et al. (2008). A strong chlorosis of the canopies in plots five and six was evident during this study and so these plots were discounted from any further analysis, as described in Liberloo et al. (2007). Daytime $\mathrm{CO}_{2}$ enrichment was provided from bud burst until bud-set except during this study when $\mathrm{CO}_{2}$ enrichment was continued throughout. The e $\left[\mathrm{CO}_{2}\right]$ measured at 1 min intervals was within a $20 \%$ deviation from the target concentration of $550 \mathrm{ppm}$ for $94 \%$ of the time during the first 3 yr rotation, and for $78 \%$ of the time during the second rotation (Liberloo et al., 2009). The leaf sampling regime is described in the Supporting Information (Methods S1) and all sampled leaves were instantly placed in foil, added to a weighted bag and dropped from the canopy to be placed in liquid $\mathrm{N}_{2}$ (from removal until placing in liquid $\mathrm{N}_{2}$ was c. $10 \mathrm{~s}$ ).

\section{Canopy level spectral reflectance}

Canopy reflectance was measured with a field portable spectroradiometer (GER 3700) (GER, Buffalo, NY, USA; Mod. 3700), and a chlorophyll-specific NDVI (Gitelson \& Merzlyak, 1994; Gamon \& Surfus, 1999) was calculated as described in Taylor et al. (2008). Further details are given in Methods S2.

\section{Microarray hybridization}

Total RNA was extracted using the protocol of Chang et al. (1993) and as described by Street et al. (2006). One hundred micrograms of total RNA was denatured $\left(65^{\circ} \mathrm{C}\right.$ for $10 \mathrm{~min}$ ) with $2 \mu \mathrm{l}$ of anchored oligo $(\mathrm{dt})_{20}$ primer and this was taken for cDNA sysnthesis. A reverse transcription master mix was prepared. This consisted of $6 \mu \mathrm{l} 5 \times$-RT-buffer (first-strand buffer), $3 \mu \mathrm{l}$ of $10 \mathrm{mM}$ Dithiothreitol (DTT), $1 \mu \mathrm{l}$ of $50 \times$ deoxynucleoside triphosphate (dNTP) mix (a mix of $\mathrm{dA}, \mathrm{dC}$ and $\mathrm{dG}$ ), and aa-dUTP and dTTP in a ratio of $4: 1$ aa-deoxyuridine-triphosphate (dUTP) : deoxythymidine-triphosphate (dTTP)) (all Amersham UK, except for aa-dUTP, which came from Sigma UK), $1 \mu$ l RNase inhibitor and $2 \mu \mathrm{l}$ Superscript ${ }^{\mathrm{TM}}$ reverse transcriptase. After overnight synthesis of cDNA at $48^{\circ} \mathrm{C}$, the reverse-transcription reaction was inhibited by addition of $10 \mu \mathrm{l} 0.5 \mathrm{M}$ EDTA and any remaining RNA was degraded by the addition of $10 \mu \mathrm{l} 1 \mathrm{M} \mathrm{NaOH}$ and heating at $65^{\circ} \mathrm{C}$ for $15 \mathrm{~min}$. The remaining cDNA was then neutralized with $50 \mu \mathrm{l}$ of 1 M Hepes ( $\mathrm{pH} 7.5$ ). The cDNA purification was carried out according to the manufacturer's instructions (Qiagen PCR purification kit) with the following exceptions. A phosphate-ethanol wash buffer (PWB: $\mathrm{pH}$ 8.0, $5 \mathrm{mM}$ $\mathrm{KPO}_{4}$ ) was used instead of buffer PE (Qiagen) and two PWB steps were included. cDNA was then eluted via two elutions each with $30 \mu \mathrm{l}$ of $0.1 \mathrm{M} \mathrm{NaHCO}_{3}$ (pH 9.0), and
$1 \mu \mathrm{l}$ of cDNA (60 $\mu \mathrm{l}$ total) was then taken for spectrometric quantification. The purified cDNA $(59 \mu \mathrm{l}$ total) was taken and $35 \mu \mathrm{l} 100 \mathrm{mM}$ sodium acetate ( $\mathrm{pH}$ 5.2) was added. Under minimal light, purified cDNA was added to an aliquot of $\mathrm{CyDye}^{\mathrm{TM}}$ ester (Amersham). Cy3 and $\mathrm{Cy} 5$ were added to the control and treatment, respectively, and for nearly $50 \%$ of the samples this orientation was reversed to account for any dye binding bias. The samples were gently agitated and then left in the dark at room temperature for $2 \mathrm{~h}$. Following a dye-coupled cDNA purification step (using the Qiagen protocol except that an additional buffer PE wash step was included and two repeated elution steps were carried out), the labelled samples were randomly paired between control and treated samples. The total elute containing $200 \mu \mathrm{l}$ Cy3-and-Cy5 coupled cDNA was concentrated down to $25 \mu \mathrm{l}$ in a spin concentrator (Eppendorf Concentrator 5301; Eppendorf, Cambridge, UK). The dyelabelled cDNA target $(25 \mu \mathrm{l})$ was denatured by the addition of $50 \mu \mathrm{l}$ formamide, $25 \mu \mathrm{l}$ hybridization buffer (Amersham) was added and the sample was heated at $95^{\circ} \mathrm{C}$ for $1 \mathrm{~min}$ and then chilled on ice.

Microarray slides were purchased from PICME (http:// www.picme.at) and were estimated to represent c. 10000 predicted gene models in the $P$. trichocarpa genome sequence (Rinaldi et al., 2007). The expressed sequence tags (ESTs) printed on the PICME poplar arrays were produced by INRA-Nancy (Rinaldi et al., 2007), INRA-Orleans (Déjardin et al., 2004) and the University of Helsinki (Brosché et al., 2005) within the framework of the LIGNOME and ESTABLISH programmes. Full MIAME-compliant details of the array content and production can be found at http://www.picme.at. An overview of the experimental design is illustrated in Fig. 1. In approach (i) a direct comparisons was conducted between replicate senescent samples (18 October) exposed to either elevated $\mathrm{CO}_{2}$ treatment

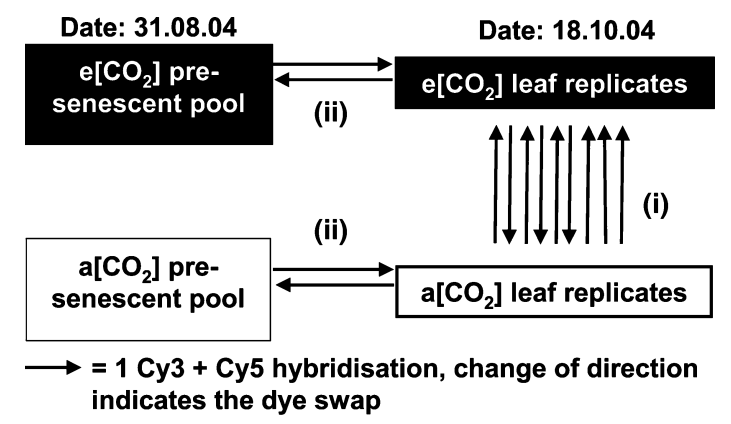

Fig. 1 A schematic representation of the microarray hybridization design. (i) Nine replicate hybridizations are shown for probes obtained from Populus leaves sampled on 18 October 2004 with each $\mathrm{CO}_{2}$ treatment represented in each hybridization. (ii) Two hybridizations are shown for senescence within each $\mathrm{CO}_{2}$ treatment. The presenescent probe for each treatment was created by pooling probes from seven replicate leaves sampled from within the respective $\mathrm{CO}_{2}$ environment. 
$\left(\mathrm{e}\left[\mathrm{CO}_{2}\right]\right)$ or ambient $\mathrm{CO}_{2}$ control $(\mathrm{a}[\mathrm{CO} 2])$. Of the 12 leaves sampled per treatment on 18 October, RNA of sufficient quality was obtained from nine leaves per treatment. These nine samples were randomly paired so that each $\mathrm{CO}_{2}$ treatment was represented in each pair. In approach (ii), comparisons between presenescent (31 August) and senescent material were undertaken using a common presenescent reference pool. For the progress of senescence in $\mathrm{a}\left[\mathrm{CO}_{2}\right]$, the $\mathrm{a}\left[\mathrm{CO}_{2}\right]$ reference pool was used and this was designated a $\left[\mathrm{CO}_{2}\right]$ senescence; in $\mathrm{e}\left[\mathrm{CO}_{2}\right]$, the $\mathrm{e}\left[\mathrm{CO}_{2}\right]$ reference pool was used and designated $\mathrm{e}\left[\mathrm{CO}_{2}\right]$ senescence. Microarray hybridizations were carried out to directly assess the transcriptome changes occurring during senescence in $\mathrm{a}\left[\mathrm{CO}_{2}\right]$ and $\mathrm{e}\left[\mathrm{CO}_{2}\right]$. RNA was extracted individually from presenescent (31 August 2004) leaves and then pooled. The pool for e $\left[\mathrm{CO}_{2}\right]$ consisted of seven samples (four from plot one and three from plot four), and the pool for a $\left[\mathrm{CO}_{2}\right]$ consisted of seven samples (four from plot two and three from plot three) (Fig. 1). In each pool, $100 \mu \mathrm{g}$ of total RNA was established using $14.3 \mu \mathrm{g}$ of total RNA from each replicate leaf.

Prehybridization, hybridization and scanning of the PICME microarray slides, and normalization of the raw expression data are described in Methods S3. Raw image spots were flagged as 'bad' and removed from further analysis if the median signal intensity was less than 256 or equal to 65535 (saturated). Images were also checked visually and abnormal spots and those far off the indexed spotting grid (dust, salt etc.) were also flagged as bad. Normalized data were then filtered based on $A$ value $\left(\left(\log _{2} R+\log _{2} G\right) / 2\right)$ to remove spots with low intensities in both channels (the threshold value for $A$ was set to 8.0, equating to a raw intensity of 256 in both channels). The transcript profile data were analysed using linear models with $B$ statistics implemented in the LIMMA (Smyth, 2004, http://bioinf.wehi. edu.au/limma/) package for the statistical software ' $R$ ' (http://www.r-project.org) to identify ESTs representing transcripts that may be differentially regulated (Diaz et al., 2003). The model contained only one specified factor for treatment, either e $\left[\mathrm{CO}_{2}\right]$ for the 18 October direct comparison between exposure to a $\left[\mathrm{CO}_{2}\right]$ and e $\left[\mathrm{CO}_{2}\right]$ (approach (i) in Fig. 1) or expression on 18 October for the comparison between the presenescent reference pools and the senescent material (approach (ii) in Fig. 1). Calculated $B$ - and $P$-values are adjusted for multiple testing with a false discover rate (FDR) of 0.05 (Benjamini \& Hochberg, 1995), which is considered a very conservative statistical analysis for FACE experiments of field-acclimated material (Leakey et al., 2009a). As the influence of senescence on transcript abundance can be very large for some transcripts (Andersson et al., 2004), this conservative statistical analysis was considered appropriate. Transcripts classed as significantly differentially expressed in e $\left[\mathrm{CO}_{2}\right]$ compared with $\mathrm{a}\left[\mathrm{CO}_{2}\right]$ late in senescence (18 October 2004) and during senescence were those represented by ESTs with a $B$-value $\geq$ 3. A $B$-value of zero is equal to a $50: 50$ probability of differential expression whereas a $B$-value of 3 represents approximately $95 \%$ certainty of differential expression $(\exp (3) /(1+\exp (3))=0.95$, or $95 \%)$. We used a $B$-value of $\geq 3$ and a twofold change in mean normalized expression as our threshold for declaring an EST as significantly differentially expressed. Expression levels for gene models were calculated from the mean data of all ESTs representing that model. Sequence annotation was obtained using the tblastx algorithm run by the DOE Joint Genome Institute (JGI, http://genome.jgi-psf.org). All microarray data generated have been deposited in the Gene Expression Omnibus (GEO) database as series GSE15874 and platforms GPL8472 and GPL8473.

\section{Analysis of expression changes for genes representing multiple biochemical pathways}

Microarray data were further analysed by MapMan (version 2.2.0; Thimm et al., 2004). Arabidopsis thaliana orthologue IDs were obtained using the gene model IDs of each EST sequence on the PICME array and the orthologue extractor function in PopGenIE (Sjödin et al., 2009). The mean $\log _{2}$ ratios for all the Populus ESTs representing single Arabidopsis orthologue gene models were used in the Mapman pathway analysis. The Wilcoxon rank sum test was used within MapMan to identify any functional group of genes that exhibit a different behaviour in terms of expression profile compared with all the other remaining functional groups. Data were Benjamini Hochberg corrected in MapMan and $P \leq 0.05$ was considered the cut-off for identifying functional groups considered to have a different behaviour in terms of expression profiles. The pathway diagrams for anthocyanin biosynthesis were based on that described for Arabidopsis (Solfanelli et al., 2006) and additional information for Populus was obtained from Tsai et al. (2006).

\section{Real-time quantitative PCR (RT-qPCR)}

The selection and validation of the internal reference gene are described in Methods S3. ESTs to be validated were searched by their EST name in the PICME database and the EST information was extracted from NCBI using accession number. Gene model information was downloaded from JGI. Real-time qPCR primers were designed using Beacon Design 5.0 (PREMIER Biosoft International, CA, USA) and the following criteria: $T_{\mathrm{m}}$ of $55-60^{\circ} \mathrm{C}$ and PCR amplicon lengths of 115-160 bp, yielding primer sequences with lengths of 19-22 nucleotides and GC contents of $45-55 \%$. Primers were also designed to amplify close to the $3^{\prime}$-end of the transcripts or EST, and at least one primer of 
New

a pair was designed to cover an exon-exon junction if possible. All primers used in this study were synthesized and desalted by Sigma-Genosys.

The protocols for cDNA synthesis and SYBR Green qPCR are described in Methods S4. The primer pairs used and mean $\mathrm{Ct}$ values of the reference gene are also reported in Methods S4.

\section{Leaf biochemistry}

Anthocyanin content frozen leaves were ground and $50 \mathrm{mg}$ from each sample was used for analysis according to the method of Martin et al. (2002). Data were calculated from the mean of three technical repeats for eight replicate leaves per treatment (four per plot).

Soluble carbohydrates and starch Extraction and measurement of glucose, fructose, sucrose and starch content have been described previously (Rogers et al., 2006). Glucose, fructose and sucrose were extracted from frozen ground material using sequential incubations in ethanol. Starch was extracted from the residual material and converted to glucose. Glucose, fructose, sucrose and the glucose resulting from the starch degradation were then assayed using a continuous enzymatic substrate assay.

\section{Statistical analysis of leaf biochemistry and spectral reflectance}

Responses of leaf biochemistry during the progression of autumnal senescence were subjected to general linear model ANOVA (using Minitab ${ }^{\circledR}$ 15.1.0.0; Minitab Inc., Philadelphia, PA, USA), with the model: response $=$ block $\mid \mathrm{CO}_{2}$ and leaf was considered the unit of replication. No significant block $\times \mathrm{CO}_{2}$ interactions were detected. Responses of canopy spectral reflectance during the progression of autumnal senescence were analysed by a two-way ANOVA with repeated measures in SPSS (SPSS 16.0 for windows) with the model: response $=$ timelCO

\section{Results and Discussion}

The trees used in this study exhibited a net increase in photosynthesis (Tricker et al., 2005; Liberloo et al., 2007), increased biomass production (Liberloo et al., 2009), a significantly reduced leaf nitrogen (on a leaf mass basis) (Liberloo et al., 2007) and were considered not to be resource-limited (Liberloo et al., 2009). Taylor et al. (2008) established that the field-grown poplar trees in this study exhibit delayed autumnal senescence in response to growth at $\mathrm{e}\left[\mathrm{CO}_{2}\right]$ (Taylor et al., 2008) and here we unravel the gene expression and biochemical changes that are associated with this response. Fig. 2a shows images across $2 \mathrm{yr}$ for the senescing canopies. A canopy-modified NDVI (a chlorophyll-
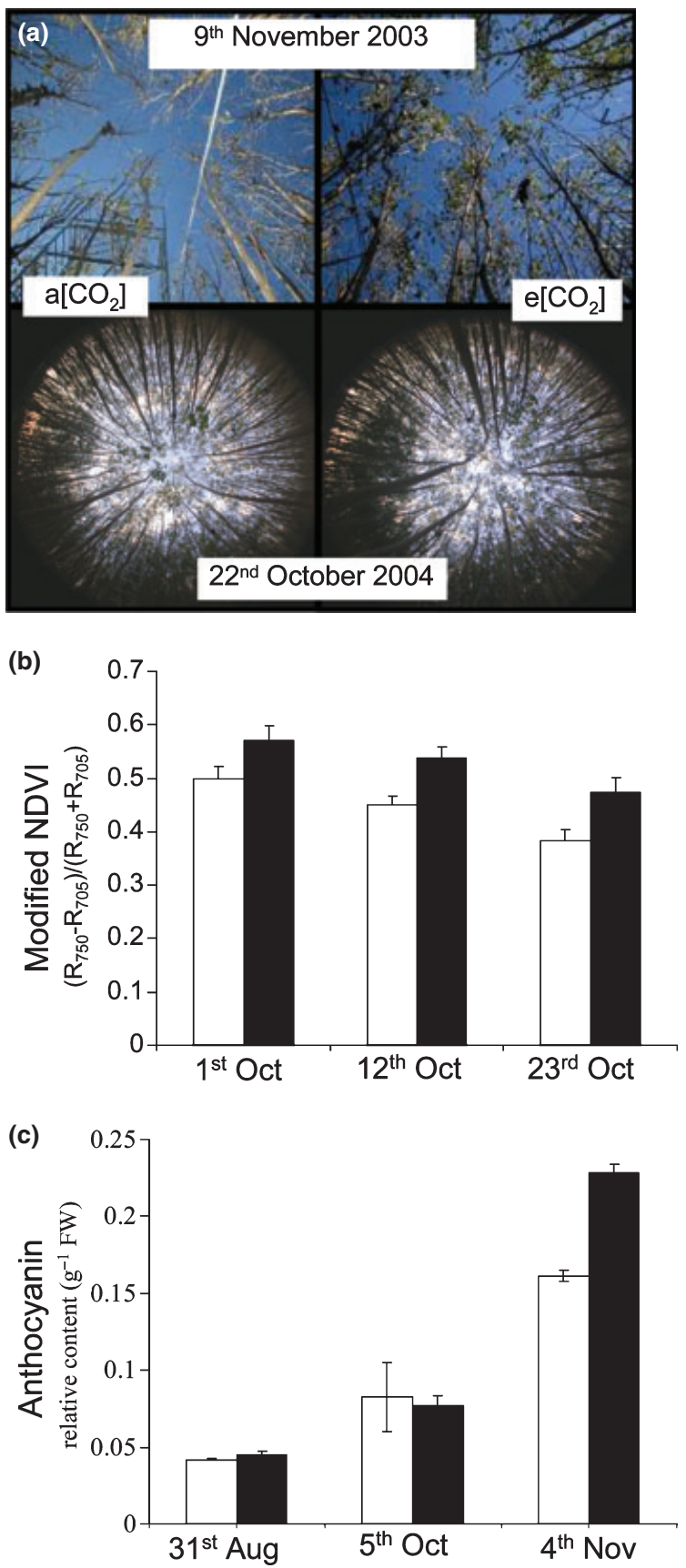

Fig. 2 The influence of elevated $\left[\mathrm{CO}_{2}\right]\left(\mathrm{e}\left[\mathrm{CO}_{2}\right]\right)$ on canopy chlorophyll content and leaf anthocyanin content during senescence in Populus. (a) Digital images of an ambient $\mathrm{CO}_{2}\left(\mathrm{a}\left[\mathrm{CO}_{2}\right]\right)$ and an $\mathrm{e}\left[\mathrm{CO}_{2}\right]$ plot during senescence and on two separate years. (b) The chlorophyll specific normalized difference vegetation index (modified NDVI, where $R_{750}$ and $R_{705}$ are the reflectance at $750 \mathrm{~nm}$ and $705 \mathrm{~nm}$ respectively) measured over the $\mathrm{e}\left[\mathrm{CO}_{2}\right]$ (closed bars) and $\mathrm{a}\left[\mathrm{CO}_{2}\right]$ (open bars) canopies at three time-points through October 2004 (mean $\pm \mathrm{SE} ; n=4$ ). (c) Extractable leaf anthocyanin content in leaves senescing in either $\mathrm{e}\left[\mathrm{CO}_{2}\right]$ (closed bars) or $\mathrm{a}\left[\mathrm{CO}_{2}\right]$ (open bars) (mean $\pm \mathrm{SE} ; n=8$ ).

specific NDVI) (Gitelson \& Merzlyak, 1994; Gamon \& Surfus, 1999) was used to estimate changes in whole-canopy 
chlorophyll content during October 2004 (Fig. 2b). As expected during senescence, modified NDVI declined significantly with time $\left(F_{2,6}=115.2, P \leq 0.001\right)$, and at all time points modified NDVI was significantly greater in $\mathrm{e}\left[\mathrm{CO}_{2}\right]\left(F_{1,3}=104.1, P \leq 0.01\right)$. This indicates that the canopy contained more chlorophyll in $\mathrm{e}\left[\mathrm{CO}_{2}\right]$ than in $\mathrm{a}\left[\mathrm{CO}_{2}\right]$ during this period and is in agreement with the extracted leaf chlorophyll content reported in Taylor $e t$ al. (2008). There was no significant interaction between $\mathrm{CO}_{2}$ treatment and time. Our study provides the first snapshot of what may be occurring within the metabolism of these trees during senescence in e $\left[\mathrm{CO}_{2}\right]$. Initially we focused on genes that exhibited a statistically significant change in regulation in $\mathrm{e}\left[\mathrm{CO}_{2}\right]$ during senescence, as evident from the microarray EST data. These data identified a significant upregulation of key transcripts in anthocyanin biosynthesis. In addition, functional groups of genes were examined which, together, exhibited a significant change in regulation. These data from direct comparison between an $\mathrm{e}\left[\mathrm{CO}_{2}\right]$ and $\mathrm{a}\left[\mathrm{CO}_{2}\right]$ late in senescence (18 October) are presented in Fig. 3. Changes in the leaf transcriptome between nonsenescent and senescent leaf material in either e $\left[\mathrm{CO}_{2}\right]$ or $\mathrm{a}\left[\mathrm{CO}_{2}\right]$ were also examined, and changes in leaf metabolism identified. These data, representing the changes between nonsenescent and senescent material, are presented in Figs 4 and 5. Leaf anthocyanin content and soluble and insoluble carbohydrate contents were also measured to support the data identified from the microarrays.

Identifying the genes most significantly influenced by $\mathrm{e}\left[\mathrm{CO}_{2}\right]$ late in autumnal senescence

The effect of senescence in $\mathrm{e}\left[\mathrm{CO}_{2}\right]$ on transcript abundance for $c .10000$ predicted gene models in the P. trichocarpa (a)
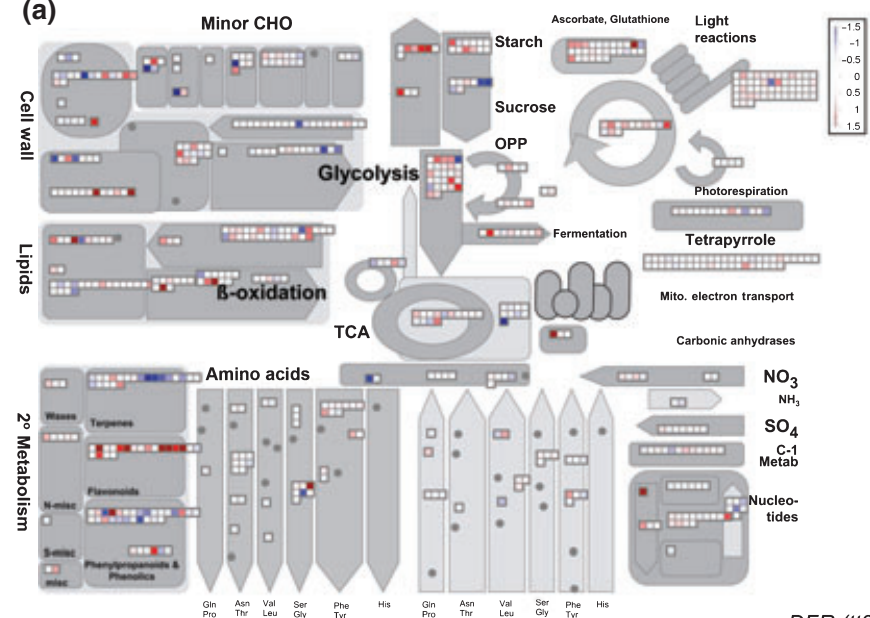

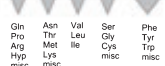
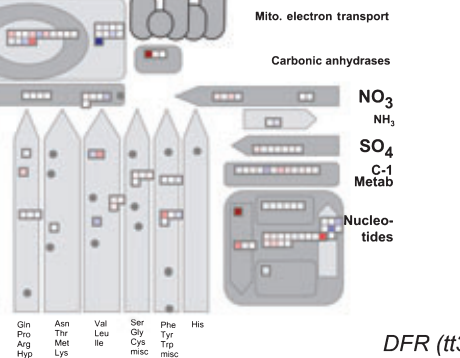

(b)
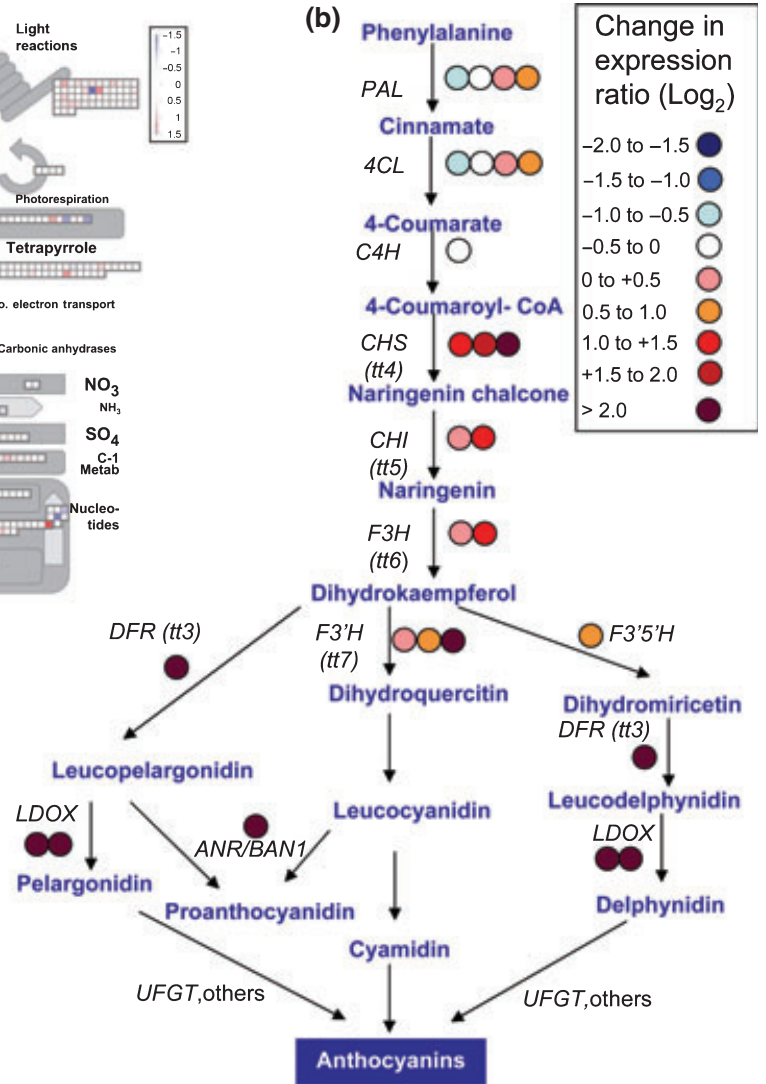

Fig. 3 A representation of transcript abundance from the late senescence (18 October 2004) microarray experiment displaying differential gene expression involved in metabolism (a) and anthocyanin biosynthesis (b). (a) Each coloured square represents the mean log ${ }_{2}$ expression data for the Arabidopsis orthologue calculated from the Populus expressed sequence tag (EST) expression data. The logarithmic colour scale bar ranges from -1.5 (dark blue, representing a threefold down-regulated gene in elevated $\left[\mathrm{CO}_{2}\right]\left(\mathrm{e}\left[\mathrm{CO}_{2}\right]\right)$ ) to +1.5 (dark red, representing a threefold up-regulated gene in $\left.{ }\left[\mathrm{CO}_{2}\right]\right)$. (b) $\mathrm{Log}_{2}$ transcript abundance data for Populus gene models involved in anthocyanin biosynthesis, as a function of $\left(e\left[\mathrm{CO}_{2}\right] /\right.$ ambient $\mathrm{CO}_{2}\left(\mathrm{a}\left[\mathrm{CO}_{2}\right]\right)$ ) expression (the logarithmic colour scale bar ranges from -2.0 to $>2.0$, dark blue to dark red). Genes coding for enzymes in this pathway were identified using the Populus EST sequence data and annotation and obtaining the Arabidopsis orthologue gene model. Coloured circles represent Populus gene models predicted to code for enzymes involved in each metabolic step. Pathway diagrams were constructed using Solfanelli et al. (2006) and Tsai et al. (2006). The expression data and annotations for (b) are given in the Supporting Information, Table S3. 
New

Phytologist

(a) (i) Up-regulated during senescence

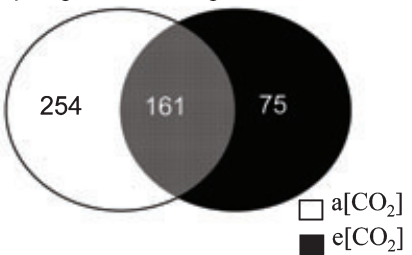

(ii) Down-regulated during senescence

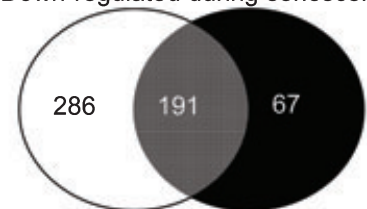

(c)

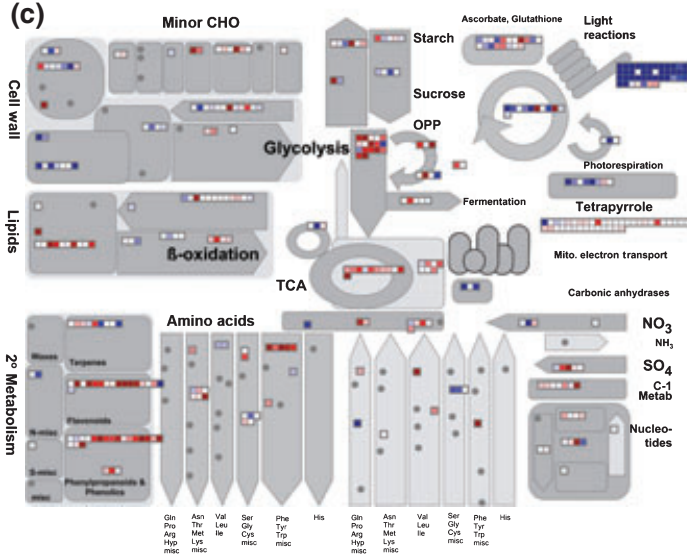

(b)

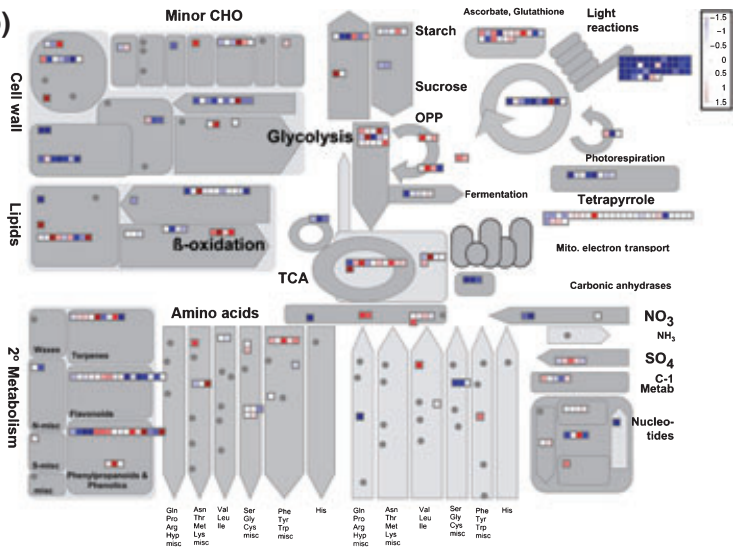

(d)

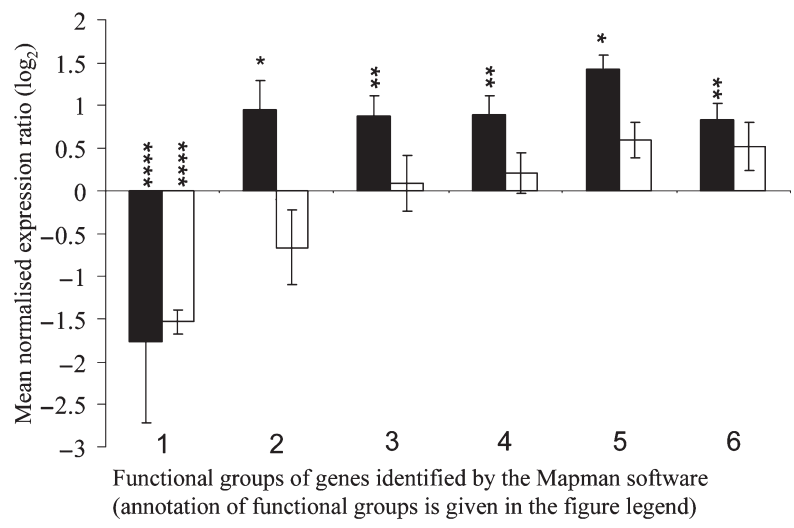

Fig. 4 A representation of transcript abundance during senescence in either ambient $\mathrm{CO}_{2}\left(a\left[\mathrm{CO}_{2}\right]\right)$ or elevated $\left[\mathrm{CO}_{2}\right]\left(e\left[\mathrm{CO}_{2}\right]\right)$. (a) Venn diagrams giving the numbers of expressed sequence tags (ESTs) representing significantly differentially expressed genes during senescence upregulated in common and unique to each $\left[\mathrm{CO}_{2}\right]$ (i), and down-regulated (ii). (b, c) MapMan metabolism overview maps representing changes in transcript abundance during senescence in $\mathrm{a}\left[\mathrm{CO}_{2}\right]$ (b) and e[CO $\left.\mathrm{CO}_{2}\right]$ (c) as a function of Populus EST expression data (18 October/31 August) within each $\mathrm{CO}_{2}$ environment averaged by Arabidopsis orthologue. The normalized expression values for all ESTs classed as significantly differentially expressed through the process of senescence in $\mathrm{e}\left[\mathrm{CO}_{2}\right]$ are reported in Supporting Information, Tables S4 and S5, and those during senescence in $\mathrm{a}\left[\mathrm{CO}_{2}\right]$ are in Tables S6 and S7. (d) The mean normalized expression ratio $\left(\log _{2}\right)$ are for those functional groups that exhibited a significantly (Benjamini Hochberg corrected Wilcoxon rank sum test) different behaviour in terms of expression profiles compared with all the other remaining groups during senescence in $\left.\mathrm{e} \mathrm{CO}_{2}\right]$ (closed bars). The expression ratio for the same group is given for senescence in a[CO $\left.{ }_{2}\right]$ (open bars) and $P$-values are reported as follows: ${ }^{*} P \leq 0.05,{ }^{*} P \leq 0.01, * * * P \leq 0.001,{ }^{*}{ }^{*} P \leq 0.0001$. Functional groups are annotated in MapMan as follows: 1, PS light reactions; 2 , secondary metabolism, flavonoids; 3, secondary metabolism, phenylpropanoids; 4, glycolysis; 5 , amino acid metabolism, synthesis, aromatic aa, chorismate; 6 . TCA cycle.

genome sequence (Rinaldi et al., 2007) was tested using the PICME microarray. Differential gene expression between $\mathrm{e}\left[\mathrm{CO}_{2}\right]$ - and a $\left[\mathrm{CO}_{2}\right]$-grown leaves was assessed on 18 October during the latter phase of senescence. Canopy leaf area index (LAI) at this time had declined by 43 and 37\% from 31 August in a $\left[\mathrm{CO}_{2}\right]$ and e $\left[\mathrm{CO}_{2}\right]$ treatments, respectively (data not shown). A robust statistical analysis using Bayesian statistics with a FDR of 0.05 was applied to identify the most consistently and significantly differentially expressed transcripts during senescence. This approach is considered by some to be very stringent for FACE experiments (Leakey et al., 2009a). For example, in the study by Taylor et al. (2005) zero transcripts would have been classed as significantly differentially expressed at this level of significance. Transcripts represented by 66 ESTs were classed as significantly differentially expressed using a Bayesian log odds
(B-stat) cut-off value of $\geq 3$. Of these, 15 were significantly up-regulated in e[CO $\left.\mathrm{CO}_{2}\right], 13$ of which were also $\geq$ twofold up-regulated and these are given in Table S1; 51 were significantly down-regulated, 38 of which were also $\geq$ twofold down-regulated and these are given in Table S2. The two most significantly differentially expressed transcripts showing the greatest increase in abundance in the $\mathrm{e}\left[\mathrm{CO}_{2}\right]$ treatment were annotated as leucoanthocyanidin dioxgenase ( $L D O X$, clone id $\mathrm{R} 71 \mathrm{~B} 12)$ and dihydroflavonol reductase (DFR, clone id RSH03D11), exhibiting a normalized change in transcript abundance $\left(\mathrm{e}\left[\mathrm{CO}_{2}\right] / \mathrm{a}\left[\mathrm{CO}_{2}\right]\right)$ of 39.6 $\left(5.3 \log _{2}\right)$ and $19.3\left(4.3 \log _{2}\right)$, respectively (Table $\left.S 1\right)$. The gene models for the two Arabidopsis orthologues of these were identified (LDOX gene model at $4 \mathrm{~g} 22880$ and DFR gene model at $5 \mathrm{~g} 42800)$ and the mean normalized increases in transcript abundance $\left(e\left[\mathrm{CO}_{2}\right] / \mathrm{a}\left[\mathrm{CO}_{2}\right]\right)$ for all (not only 
(a)
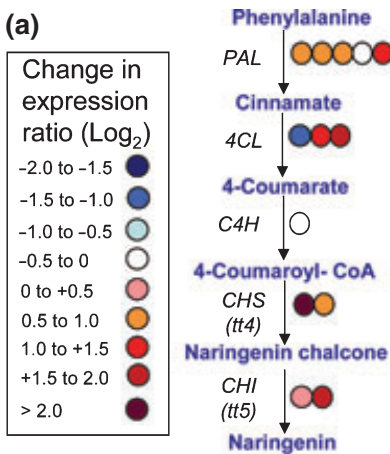

Naringenin

F3H

(tt6)

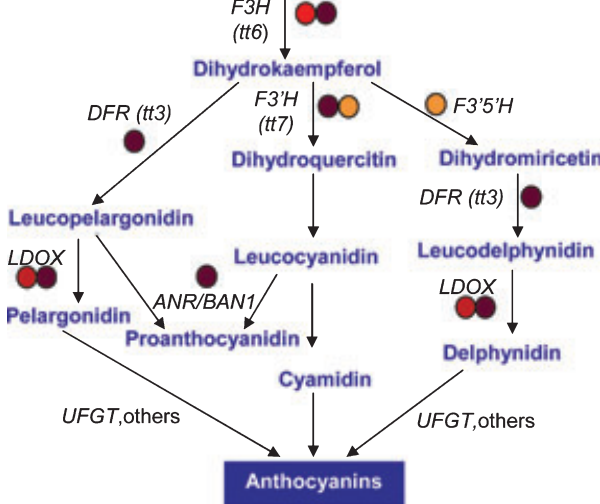

(b)

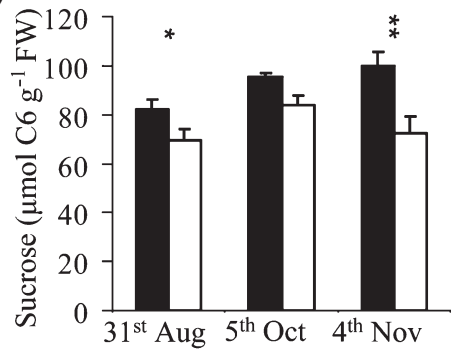

(c)

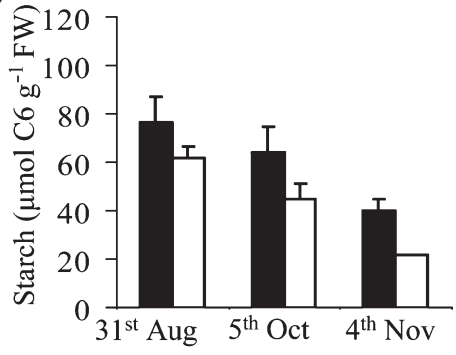

Fig. 5 The influence of elevated $\left[\mathrm{CO}_{2}\right]\left(\mathrm{e}\left[\mathrm{CO}_{2}\right]\right)$ on gene expression within the anthocyanin biosynthetic pathway and leaf sucrose and starch content during senescence (between 31 August and 18 October). (a) $\log _{2}$ expression data for Populus gene model from two replicate hybridizations for each $\mathrm{CO}_{2}$ treatment calculated as ((e[CO2] 18 October/31 August)/(ambient $\mathrm{CO}_{2}\left(\mathrm{a}\left[\mathrm{CO}_{2}\right]\right) 18$ October/31 August)). The pathway diagram was constructed using Solfanelli et al. (2006) and Tsai et al. (2006). The expression data and annotations for (a) are given in Supporting Information, Table S9. (b, c) Data for leaf sucrose (b) and starch content (c) in both a[CO $\left.\mathrm{CO}_{2}\right]$ (open bars) and e[CO $\left.\mathrm{CO}_{2}\right]$ (closed bars) $(n=8)$. $P$-values are reported as follows: ${ }^{*} P \leq 0.05,{ }^{*} P \leq 0.01,{ }^{*}{ }^{*} P \leq 0.001$; where no $P$-value is reported, data were not significant.

those classed as significant) of the Populus ESTs showing homology to these Arabidopsis orthologues were 16.7 $\left(4.1 \log _{2}\right)$ and $30.2\left(4.9 \log _{2}\right)$, respectively. These two transcripts code for enzymes in the anthocyanin biosynthetic pathway of Populus (Tsai et al., 2006). Correlations between these changes in transcript abundance and leaf anthocyanin content were investigated, with anthocyanin content measured on three occasions in August, October and November. Irrespective of $\mathrm{CO}_{2}$ treatment, leaf anthocyanin increased over time from late August to early November, as expected during senescence (Keskitalo et al., 2005). Although not statistically significant, anthocyanin content had increased by $413 \%$ in e $\left[\mathrm{CO}_{2}\right]$ compared with a $342 \%$ increase in $\mathrm{a}\left[\mathrm{CO}_{2}\right]$ between 31 August and 4 November, resulting in a $23 \%$ increase in the anthocyanin content by 4 November in e $\left[\mathrm{CO}_{2}\right]$ compared with a $\left[\mathrm{CO}_{2}\right]$ (Fig. 2c).

Identifying the pathways most significantly influenced by $\mathrm{e}\left[\mathrm{CO}_{2}\right]$ late in autumnal senescence

Although a relationship between mRNA and protein concentrations can be inferred here for anthocyanin biosynthesis, this may often not be the case (Feder \& Walser, 2005). Therefore, by grouping genes into functional categories,
Andersson et al. (2004) considered that mean values should represent a good approximation of the relative effort that plants are making to synthesize the proteins of the respective categories. Using the pathway analysis software MapMan (http://gabi.rzpd.de/projects/MapMan/), the metabolism overview map was explored against the Arabidopsis TAIR 8 database. Functional groups of genes which together exhibit a statistically significantly different behaviour in terms of expression profiles compared with all the other remaining functional groups were identified. The mean expression data were calculated for each EST passing the quality controls (i.e. not flagged as bad) from the late senescent replicate microarray hybridizations. Of the 13241 ESTs with expression data, 12491 exhibited homology with the Arabidopsis genome, and unique Arabidopsis orthologue gene models numbered 4712. The mean $\log _{2}$ expression data for each Arabidopsis orthologue was imported into MapMan and the functional groups within the metabolism class were analysed (Fig. 3a). The statistically significant differentially regulated functional groups (BINs) were BIN 16.8 secondary metabolism of flavonoid biosynthesis $P \leq 0.02$ (mean normalized expression ratio, $\left.e / a=4.56\left(2.19 \log _{2}\right)\right)$ and BIN 4 glycolysis $P \leq 0.04$ (mean normalized expression ratio, $e / a=2.39$ 
$\left.\left(1.26 \log _{2}\right)\right)$. This approach provided further support for up-regulation of secondary metabolism, leading to anthocyanin biosynthesis in $\mathrm{e}\left[\mathrm{CO}_{2}\right]$ compared with a $\left[\mathrm{CO}_{2}\right]$-grown leaves.

In Populus the flavonoid biosynthetic pathway contains increased gene copy numbers for many enzymes when compared with Arabidopsis (Tsai et al., 2006) and so the mean expression data for each Populus gene model was used. Fig. 3b shows that transcript abundance for enzymes catalysing the biosynthetic pathway from phenylalanine to anthocyanin were generally increased in e $\left[\mathrm{CO}_{2}\right]$. Table $\mathrm{S} 3$ gives the expression data for each EST, Populus gene models and the Arabidopsis orthologues used in Fig. 3(b). The variance for multiple ESTs forming expression data for individual gene models is also given. Although post-transcriptional processes play an important role in regulating metabolism, the greater transcript abundance for nearly the entire pathway (rather than just a small number of enzymes) provides strong evidence for a transcriptionally driven mechanism responding to $\mathrm{e}\left[\mathrm{CO}_{2}\right]$ and leading to increased anthocyanin biosynthesis. Anthocyanin pigments have a multifaceted protective role in leaves, including protection from UV damage, pathogens, photoinhibiton, photo-oxidative stress and scavenging free radicals (Gould, 2004). The increased anthocyanin biosynthesis seen here is consistent with the idea that induction of stress-responsive pathways can extend the viability of senescing cells (Buchanan-Wollaston et al., 2005). Diaz et al. (2006) suggest that anthocyanin may influence leaf life span by protecting from photo-oxidative stress, and Schaberg et al. (2008) identified a delay in abscission layer formation during autumnal senescence in sugar maple leaves containing increased anthocyanin.

Identifying the genes most significantly influenced by e $\left[\mathrm{CO}_{2}\right]$ during the progression of autumnal senescence

To determine whether this shift in metabolism late in senescence was in response to delayed senescence, changes in leaf transcript abundance and selected metabolites were examined. Differential gene expression between the presenescent (31 August) and the senescent canopies (18 October) was investigated (Fig. 4) using RNA from a presenescent reference pool, similar to the approach of Andersson et al. (2004). During senescence in $a\left[\mathrm{CO}_{2}\right]$, normalized transcript abundance was calculated as (18 October/31 August) and 892 ESTs representing 417 unique Populus gene models were significantly differentially expressed ( $\geq 3 B$-value and $\geq$ twofold change). In the e $\left[\mathrm{CO}_{2}\right]$-treated canopies, 494 ESTs representing 196 unique Populus gene models were classed as significantly differentially expressed; fewer ESTs representing significantly differentially expressed transcripts occurred in e $\left[\mathrm{CO}_{2}\right]$ (Fig. 4a). These differences are interesting as they suggest that the senescence transcrip- tional programme was disrupted by the $\mathrm{e}\left[\mathrm{CO}_{2}\right]$ treatment. Using a different microarray platform, Andersson et al. (2004) identified 201 ESTs representing 166 unique Populus gene models as the most up-regulated during senescence in Populus tremula. The ESTs representing transcripts exhibiting a twofold change in normalized transcript abundance and a significant $B$-value, and unique to senescence in each $\mathrm{CO}_{2}$ environment, are reported in Tables S4-S7. Although the Andersson et al. (2004) study and the data reported here used different microarray platforms, of the significantly upregulated transcripts during senescence in $\mathrm{e}\left[\mathrm{CO}_{2}\right]$, only seven had commonality with Andersson's up-regulated list, whilst in a $\left[\mathrm{CO}_{2}\right]$ this numbered 15 (EST data for these are reported in Table S8). Beyond the use of different microarray platforms, the lack of commonality in expression changes during senescence between these studies is a surprise. Species differences, tree environment and leaf position in the tree (upper canopy in this study and lower canopy in Andersson et al. (2004)) were also very different which may begin to explain some of the differences seen. The onset of senescence is strongly controlled by changing photoperiod; however, the lack of commonality here may indicate how different biotic and abiotic factors influence the progression of senescence. Systemic differences between these studies (i.e. methodology for declaring EST data as significant) may also account for the lack of commonality. During senescence in $\mathrm{e}\left[\mathrm{CO}_{2}\right]$, ESTs representing four Arabidopsis orthologue gene models in the anthocyanin biosynthetic pathway were among the most abundant (Table S4). These represented the Arabidopsis orthologue gene models: at4g22880 (LDOX), at5g42800 (DFR), at2g37040 (Phenylalanine ammonia lyase, PAL1) and at5g05270 (chalcone-flavanone isomerise, $C H I)$. The mean normalized increases in transcript abundance in $\mathrm{e}\left[\mathrm{CO}_{2}\right]$ were $20.26 \quad\left(4.3 \log _{2}\right), 12.75$ $\left(3.7 \log _{2}\right), 8.36\left(3.1 \log _{2}\right)$ and $6.31\left(2.7 \log _{2}\right)$, respectively, for each of these gene models. Of these gene models, both those expressing the products LDOX and DFR were among those that were at least fourfold up-regulated and $\mathrm{CHI}$ was between two- and fourfold up-regulated during the development of bud dormancy in Populus (Ruttink et al., 2007).

Identifying the pathways most significantly influenced by $\mathrm{e}\left[\mathrm{CO}_{2}\right]$ during the progression of senescence

The MapMan software was used to identify functional groups of genes which together exhibited a significantly different behaviour in expression during the progression of senescence in either $\mathrm{a}\left[\mathrm{CO}_{2}\right]$ or $\mathrm{e}\left[\mathrm{CO}_{2}\right]$ (18 October/31 August), with data presented in Fig. 4(b)-(d). To identify changes in transcript abundance between senescence in $\mathrm{a}\left[\mathrm{CO}_{2}\right]$ and senescence in $\mathrm{e}\left[\mathrm{CO}_{2}\right]$ the sequences for all expression data represented by ESTs existing in both $\mathrm{CO}_{2}$ environments and passing quality control were taken. These 
numbered 7404 ESTs: 7171 showed homology to Arabidopsis and, of these sequences, 2148 were classed as unique Arabidopsis orthologue gene models. Figure 4(b) represents functional groups within the metabolism overview in $\mathrm{a}\left[\mathrm{CO}_{2}\right]$ and Fig. 4(c) represents groups in e $\left[\mathrm{CO}_{2}\right]$. In both $\mathrm{CO}_{2}$ environments, these figures show a significant downregulation of genes involved in the light reactions of photosynthesis, as would be expected. It is notable that the mean down-regulation of this functional group was greater in $\mathrm{e}\left[\mathrm{CO}_{2}\right]$ than in a $\left[\mathrm{CO}_{2}\right]$ (Fig. $4 \mathrm{~d}$ ). It is possible that anthocyanin accumulation results in a stabilization of photosynthetic proteins and pigments in $\mathrm{e}\left[\mathrm{CO}_{2}\right]$, and thus delayed functional senescence despite induction of the senescence programme at the transcriptional level. During senescence in $\mathrm{e}\left[\mathrm{CO}_{2}\right]$, the phenylpropanoid and flavonoid biosynthetic pathways were significantly up-regulated (18 October/31 August), $1.84\left(0.88 \log _{2}\right)$ and $1.93\left(0.95 \log _{2}\right)$, respectively, while during senescence in $\mathrm{a}\left[\mathrm{CO}_{2}\right]$ the flavonoid biosynthetic pathway was down-regulated $0.63\left(-0.67 \log _{2}\right)$ (Fig. 4d). Studies of developing and mature soybean have shown an e $\left[\mathrm{CO}_{2}\right]$-induced increase in transcripts associated with glycolysis (Ainsworth et al., 2006; Leakey et al., 2009b) and data here support this. Both the glycolytic pathway and the TCA cycle were significantly up-regulated during senescence in $\mathrm{e}\left[\mathrm{CO}_{2}\right]$, as were genes for enzymes of the shikimate pathway leading to chorismate biosynthesis, a precursor for the aromatic amino acids such as phenylalanine (Fig. 4d). Taken together, these data indicate a shift in metabolism between senescence in $\mathrm{a}\left[\mathrm{CO}_{2}\right]$ and $\mathrm{e}\left[\mathrm{CO}_{2}\right]$, which appears to coincide with an up-regulation of glycolysis and secondary metabolism. The change in transcript abundance was calculated from EST expression data as a function of (senescence in $\left.\mathrm{e}\left[\mathrm{CO}_{2}\right]\right) /\left(\right.$ senescence in a $\left[\mathrm{CO}_{2}\right]$ ), and the mean Populus gene model expression data for the anthocyanin biosynthetic pathway is given in Fig. 5(a). The pathway analysis (Fig. 5a) and data from the EST statistical analysis (Table S4) all indicate an active up-regulation of the anthocyanin pathway during the progress of senescence in $\mathrm{e}\left[\mathrm{CO}_{2}\right]$ compared with that in $\mathrm{a}\left[\mathrm{CO}_{2}\right]$. This supports the transcript data obtained from a direct comparison between $\mathrm{CO}_{2}$ growth environments late in senescence (Fig. 3b) and the leaf anthocyanin content data (Fig. 2c).

\section{Leaf carbohydrate contents}

As photosynthate production declines during the active process of senescence, energy is generated by mitochondrial respiration through processes such as beta-oxidation (Andersson et al., 2004). During senescence in $\mathrm{e}\left[\mathrm{CO}_{2}\right]$, it could be postulated that metabolism through glycolysis was still sufficient for energy generation, and the products of this metabolism were used in flavonoid biosynthesis. If this were the case, substrate for glycolysis should be present in $\mathrm{e}\left[\mathrm{CO}_{2}\right]$-exposed leaves and beta-oxidation could be expected to be up-regulated in the a $\left[\mathrm{CO}_{2}\right]$ leaves. Although not classed as a significantly up-regulated functional group, those genes comprising BIN 11.9.4.2: (lipid metabolism.lipid degradation.beta-oxidation) exhibited increases in mean normalized expression during senescence in a $\left[\mathrm{CO}_{2}\right]$ compared with $\mathrm{e}\left[\mathrm{CO}_{2}\right]$ of $4.20\left(2.07 \log _{2}\right)$ and 3.07 $\left(1.62 \log _{2}\right)$, respectively (data not shown, but extracted from Fig. 4b,c). Sucrose and starch contents were increased in $\mathrm{e}\left[\mathrm{CO}_{2}\right]$, although this was only significant at two time points and only for sucrose (Fig. 5b,c). A gradual increase in sucrose content was apparent from August to November in $\mathrm{e}\left[\mathrm{CO}_{2}\right]$ (Fig. 5b). This is in contrast to leaves sampled in the growing season before the onset of senescence and during a preceding year where, in $\mathrm{e}\left[\mathrm{CO}_{2}\right]$, no accumulation of sucrose or hexoses were observed (Davey et al., 2006). During senescence, starch content declined in all leaves, suggesting that catabolism contributed to the energy requirements of the leaf (Fig. 5c). Glucose and fructose contents are reported in Fig. S1. During senescence, the glucose content of leaves decreased and no significant difference was reported between treatments for either glucose or fructose.

\section{Additional microarray confirmation using RT-qPCR}

Transcript abundance data derived from the microarray hybridizations for the pathways reported here are consistent with the findings from leaf biochemical assays of anthocyanin and carbohydrate contents. Real-time qPCR was used to further assess the reliability of the microarray data and particularly to observe the $\mathrm{CO}_{2}$ influences on $L D O X$ transcript abundance. Primers were designed against the sequences of three genes up-regulated and three down-regulated in $\mathrm{e}\left[\mathrm{CO}_{2}\right]$ on 18 October. The expression of these genes was quantified using RT-qPCR and normalized with PDF1 as a reference gene. Fig. S2 shows good confirmation between the microarray data and those from RT-qPCR. The relative expression of $L D O X$ between the late growing season and late senescence samples was also examined using RT-qPCR. A clear up-regulation of $L D O X$ during senescence in $\mathrm{e}\left[\mathrm{CO}_{2}\right]$ can be seen, with the opposite occurring in $\mathrm{a}\left[\mathrm{CO}_{2}\right]$ (Fig. S2, inset).

\section{Summary}

Once autumnal senescence in Populus is initiated by a change in photoperiod (Olsen et al., 1997; Keskitalo et al., 2005; Böhlenius et al., 2006), the balance between reactive oxygen species (ROS) production and ROS scavenging can determine the rate of senescence (McKersie et al., 1988; Buchanan-Wollaston et al., 2003; Gepstein et al., 2003). We have shown that leaf sucrose content was significantly increased by exposure to e $\left[\mathrm{CO}_{2}\right]$, while glucose and fructose were not affected, and that this may act as a signal to stimulate the synthesis of anthocyanin. This supports findings in 
several contrasting plant species and organs and is supported by work on the mutant pho3 (Lloyd \& Zakhleniuk, 2004). In this sucrose-export mutant (pho3), LDOX and $D F R$ were up-regulated by 190 and 31 times, respectively, again linking leaf sucrose content and anthocyanin biosynthesis. Direct sugar induction of anthocyanin biosynthesis in Arabidopsis has also been reported (Teng et al., 2005; Solfanelli et al., 2006). Furthermore, the association between $\mathrm{e}\left[\mathrm{CO}_{2}\right]$ and the partitioning of carbon to the synthesis of secondary metabolites was evident in tobacco plants exposed to an e[CO $\left.\mathrm{CO}_{2}\right]$ of $1000 \mathrm{ppm}$ (Matros et al., 2006). The Matros et al. (2006) study provides evidence for a direct link between $\mathrm{e}\left[\mathrm{CO}_{2}\right]$, an increased leaf $\mathrm{C}: \mathrm{N}$ ratio and an increased activity of phenylalanine ammonia lyase (PAL), a key enzyme catalysing the first committed step in the biosynthesis of phenylpropanoids, with a concomitant increase of secondary metabolites. Long-lived trees, such as Populus, have evolved strategies for defence, dormancy and wood formation that may not be well represented in the genomes of annuals such as Arabidopsis. Enzymes involved in the flavonoid biosynthetic pathway leading to anthocyanin production are coded by multiple copy genes in Populus and generally single copy genes in Arabidopsis, for example, LDOX and DFR (Tsai et al., 2006). This study further highlights the importance of using Populus as a model to study natural autumnal senescence (Jansson \& Douglas, 2007) and the open-field environment as essential to gaining a mechanistic understanding of how trees may respond in the natural environment, using fully replicated and designed field experimentation (Taylor et al., 2005).

In conclusion, we have identified an association between delayed autumnal senescence in $\mathrm{e}\left[\mathrm{CO}_{2}\right]$, with a change in leaf carbohydrate status, gene expression profiles and anthocyanin content. It is possible that this may be a secondary response to other factors. For example, canopy temperature is often increased during growth in $\mathrm{e}\left[\mathrm{CO}_{2}\right]$ at FACE sites, as is evident for soybean (Long et al., 2006). Nevertheless the data reported here begin to identify processes by which climate change can influence plant phenology, although further work will be required to provide evidence of a causal relationship between $\mathrm{e}\left[\mathrm{CO}_{2}\right]$, carbohydrate metabolism, anthocyanin biosynthesis and delayed senescence. The most conspicuous change in gene expression was for genes involved in the biosynthetic pathway of anthocyanin; they were strongly and significantly induced in $\mathrm{e}\left[\mathrm{CO}_{2}\right]$, resulting in an increased leaf anthocyanin content. The sucrose content of senescing leaves was also increased in $\mathrm{e}\left[\mathrm{CO}_{2}\right]$ and we propose that excess carbon in $\mathrm{e}\left[\mathrm{CO}_{2}\right]$ is available to be partitioned to carbon-rich secondary metabolites, such as anthocyanin, which provides a protective role in senescing leaves, extending leaf longevity. This $\mathrm{CO}_{2}$-stimulated shift in metabolism is consistent with the growth/differentiation balance hypothesis extended by Herms \& Mattson (1992) and observed in forest studies (Harding et al., 2005; Mattson et al., 2005; Cseke et al., 2009). We have begun to identify the genetic mechanisms for adaptation to future $\mathrm{CO}_{2}$, but the long-term consequences of such changes for forest ecosystem function and microevolutionary adaptation remain uncertain.

\section{Acknowledgements}

This research was supported by the European Commission through the Directorate General Research within the Fifth Framework for Research - Quality of Life and Management of the Living Resources Programme, contract number QLK5-CT-2002-00953 (POPYOMICS), coordinated by the University of Southampton. The POPFACE experiment within the EUROFACE infrastructure was supported by the EC through its Environment R\&D programme within the Fourth Framework as a research contract ENV4CT97-0657 (POPFACE) and within the Fifth Framework as contract EVR1-CT-2002-40027 (EUROFACE) coordinated by Giuseppe Scarascia-Mugnozza at the University of Viterbo. This research was also supported by the Office of Science (BER), US Department of Energy, grant no. DEFG02-04ER63792, 'POPGENICS' awarded to GT and DFK. AR was supported by the US Department of Energy Office of Science grant no. DEFG02-04ER63792 and by contract no. DE-AC02-98CH10886 to Brookhaven National Laboratory. Research in the laboratory of GT was also supported by the DEFRA project BEGIN and the Seventh Framework Network of Excellence, EVOLTREE. The authors thank B. Gielen, C. Calfapietra, T. Oro, GJJ Clarkson, M. Pecchiari and C. Steynen for help in the field, and L. E. Graham and J. Tucker for help with the microarray hybridizations. A. Zaldei is thanked for support of the infrastructure at the POPFACE field site.

\section{References}

Ainsworth EA, Rogers A, Nelson R, Long SP. 2004. Testing the "sourcesink" hypothesis of down-regulation of photosynthesis in elevated $\left[\mathrm{CO}_{2}\right]$ in the field with single gene substitutions in Glycine max. Agricultural and Forest Meteorology 122: 85-94.

Ainsworth EA, Rogers A, Vodkin LO, Walter A, Schurr U. 2006. The effects of elevated $\mathrm{CO}_{2}$ concentration on soybean gene expression. An analysis of growing and mature leaves. Plant Physiology 142: 135-147.

Andersson A, Keskitalo J, Sjodin A, Bhalerao R, Sterky F, Wissel K, Tandre K, Aspeborg H, Moyle R, Ohmiya Y et al. 2004. A transcriptional timetable of autumn senescence. Genome Biology 5: R24.1R24.13.

Benjamini Y, Hochberg Y. 1995. Controlling the false discovery rate: a practical and powerful approach to multiple testing. Journal of the Royal Statistical Society. Series B (Methodological) 57: 289-300.

Böhlenius H, Huang T, Charbonnel-Campaa L, Brunner AM, Jansson S, Strauss SH, Nilsson O. 2006. CO/FT regulatory module controls timing of flowering and seasonal growth cessation in trees. Science 312: $1040-1043$. 
Brosché M, Vinocur B, Alatalo ER, Lamminmaki A, Teichmann T, Ottow EA, Djilianov D, Afif D, Bogeat-Triboulot MB, Altman A et al. 2005. Gene expression and metabolite profiling of Populus euphratica growing in the Negev desert. Genome Biology 6: art.

Bryant JB, Taylor G, Frehner M. 1998. Photosynthetic acclimation in chalk grassland herbs exposed to elevated $\mathrm{CO}_{2}$ in a FACE system. Plant, Cell \& Environment 21: 159-168.

Buchanan-Wollaston V, Earl S, Harrison E, Mathas E, Navabpour S, Page T, Pink D. 2003. The molecular analysis of leaf senescence - a genomics approach. Plant Biotechnology Journal 1: 3-22.

Buchanan-Wollaston V, Page T, Harrison E, Breeze E, Lim PO, Nam HG, Lin J-F, Wu S-H, Swidzinski J, Ishizaki K et al. 2005. Comparartive transcriptome analysis reveals significant differences in gene expression and signalling pathways between developmental and dark/starvation-induced senescence in Arabidopsis. Plant Journal 42 567-585.

Chang S, Puryear J, Cairney J. 1993. A simple and efficient method for isolating RNA from pine trees. Plant Molecular Biology Reporter 11: 113-116.

Chen WJ, Black TA, Yang PC, Barr AG, Neumann HH, Nesic Z, Blanken PD, Novak MD, Eley J, Ketler RJ et al. 1999. Effects of climatic variability on the annual carbon sequestration by a boreal aspen forest. Global Change Biology 5: 41-53.

Cseke LJ, Tsai C-J, Rogers A, Nelson MP, White HL, Karnosky DF, Podila GK. 2009. Transcriptomic comparison in the leaves of two aspen genotypes having similar carbon assimilation rates but different allocation patterns under elevated $\mathrm{CO}_{2}$. New Phytologist 182: 891-911.

Davey PA, Olcer H, Zakhleniuk O, Bernacchi CJ, Calfapietra C, Long SP, Raines CA. 2006. Can fast-growing plantation trees escape biochemical down-regulation of photosynthesis when grown throughout their complete production cycle in the open air under elevated carbon dioxide? Plant, Cell \& Environment 29: 1235-1244.

Déjardin A, Leplé J-C, Lesage-Descauses M-C, Costa G, Pilate G. 2004. Expressed Sequence Tags from poplar wood tissues - a comparative analysis from multiple libraries. Plant Biology 6: 55-64.

Diaz E, Yang YH, Ferreira T, Loh KC, Okazaki Y, Hayashizaki Y, Tessier-Lavingne M, Speed TP, Ngai J. 2003. Analysis of gene expression in the developing mouse retina. Proceedings of the National Academy of Sciences, USA 100: 5491-5496.

Diaz C, Saliba-Colombani V, Loudet O, Belluomo P, Moreau L, DanielVedele F, Morot-Gaudry J-F, Masclaux-Daubresse C. 2006. Leaf yellowing and anthocyanin accumulation are two genetically independent strategies in response to nitrogen limitation in Arabidopsis thaliana. Plant and Cell Physiology 47: 74-83.

Feder ME, Walser JC. 2005. The biological limitations of transcriptomics in elucidating stress and stress responses. Journal of Evolutionary Biology 18: 901-910.

Fracheboud Y, Luquez V, Björkén L, Sjödin A, Tuominen H, Jansson S. 2009. The control of autumn senescence in European Aspen. Plant Physiology 149: 1982-1991.

Gamon JA, Surfus JS. 1999. Assessing leaf pigment content and activity with a reflectometer. New Phytologist 143: 105-117.

Gepstein S, Sabehi G, Carp M-J, Hajouj T, Nesher MFO, Yariv I, Dor C, Bassani M. 2003. Large-scale identification of leaf senescence-associated genes. Plant Journal 36: 629-642.

Gitelson AA, Merzlyak MN. 1994. Spectral reflectance changes associated with autumn senescence of Aesculus-Hippocastanum $\mathrm{L}$ and AcerPlatanoides L leaves - spectral features and relation to chlorophyll estimation. Journal of Plant Physiology 143: 286-292.

Gould KS. 2004. Natures Swiss army knife: the diverse protective roles of anthocyanins in leaves. Journal of Biomedicine and Biotechnology 5: 314320.

Harding SA, Jiang H, Jeong ML, Casado FL, Lin H-W, Tsai C-J. 2005. Functional genomics analysis of foliar condensed tannin and phenolic glycoside regulation in natural cottonwood hybrids. Tree Physiology 25: 1475-1486.

Herms DA, Mattson WJ. 1992. The dilemma of plants: to grow or defend. The Quarterly Review of Biology 67: 283-335.

Herrick JD, Thomas RB. 2003. Leaf senescence and late-season net photosynthesis of sun and shade leaves of overstory sweetgum (Liquidambar styraciflua) grown in elevated and ambient carbon dioxide concentrations. Tree Physiology 23: 109-118.

Ingvarsson PK, Garcia MV, Hall D, Luquez V, Jansson S. 2006. Clinal variation in $p h y B 2$, a candidate gene for day-lengh induced growth cessation and bud set, across a latitudinal gradient in European aspen (Populus tremula). Genetics 172: 1845-1853.

Jansson S, Douglas C. 2007. Populus: a model system for plant biology. Annual Review of Plant Biology 58: 435-458.

Kaschuk G, Hungria M, Leffelaar PA, Giller KE, Kuyper TW. 2009. Differences in photosynthetic behaviour and leaf senescence of soybean (Glycine max [L.] Merrill) dependent on $\mathrm{N}_{2}$ fixation or nitrate supply. Plant Biology 12: 60-69.

Keskitalo J, Bergquist G, Gardeström P, Jansson S. 2005. A cellular timetable of autumnal senescence. Plant Physiology 139: 1635-1648.

Leakey ADB, Ainsworth EA, Bernard SM, Cody Markelz RJ, Ort DR, Placella SA, Rogers A, Smith MD, Sudderth EA, Weston DJ et al. 2009a. Gene expression profiling: opening the black box of plant ecosystem responses to global change. Global Change Biology 15: 1201-1213.

Leakey ADB, Xu F, Gillespie KM, McGrath JM, Ainsworth EA, Ort DR. 2009b. Genomic basis for stimulated respiration by plants growing under elevated carbon dioxide. Proceedings of the National Academy of Sciences, USA 106: 3597-3602.

Li J-H, Dijkstra P, Hymus GJ, Wheeler RM, Piastuch WC, Hinkle CR, Drake BG. 2000. Leaf senescence of Quercus myrtifolia as affected by long-term $\mathrm{CO}_{2}$ enrichment in its native environment. Global Change Biology 6: 727-733.

Liberloo M, Lukac M, Calfapietra C, Hoosbeek MR, Gielen B, Miglietta F, Scarascia-Mugnozza GE, Ceulemans R. 2009. Coppicing shifts $\mathrm{CO}_{2}$ stimulation of poplar productivity to above-ground pools: a synthesis of leaf to stand level results from the POP/EUROFACE experiment. New Phytologist 182: 331-346.

Liberloo M, Tulva I, Raïm O, Ceulemans R. 2007. Photosynthetic stimulation under long-term $\mathrm{CO}_{2}$ enrichment and fertilization is sustained across a closed Populus canopy profile (EUROFACE). New Phytologist 173: 537-549.

Lloyd JC, Zakhleniuk OV. 2004. Responses of primary and secondary metabolism to sugar accumulation revealed by microarray expression analysis of the Arabidopsis mutant, pho3. Journal of Experimental Botany 55: 1221-1230.

Long SP, Ainsworth EA, Leakey ADB, Nösberger J, Ort DR. 2006. Food for thought: lower-than-expected crop yield stimulation with rising $\mathrm{CO}_{2}$ concentrations. Science 312: 1918-1921.

Lucht W, Prentice CI, Myneni RB, Sitch S, Friedlingstein P, Cramer W, Bousquet P, Buermann W, Smith B. 2002. Climatic control of the high-latitude vegetation greening trend and Pinatubo effect. Science 296: $1687-1688$

Martin T, Oswald O, Graham IA. 2002. Arabidopsis seedling growth, storage lipid mobilization, and photosynthetic gene expression are regulated by carbon : nitrogen availability. Plant Physiology 128: 472-481.

Matros A, Amme S, Kettig B, Buck-Sorlin GH, Sonnewald U, Mock H-P. 2006. Growth at elevated $\mathrm{CO}_{2}$ concentrations leads to modified profiles of secondary metabolites in tobacco cv. SamsunNN and to increased resistance against infection with potato virus Y. Plant, Cell \& Environment 29: 126-137.

Mattson WJ, Julkunen-Tiitto R, Herms DA. 2005. $\mathrm{CO}_{2}$ enrichment and carbon partitioning to phenolics: do plant responses accord better with the protein competition or the growth-differentiation balance models? Oikos 111: 337-347. 
McKersie BD, Senaratna T, Walker MA, Kendall EJ, Hetherington PR. 1988. Deterioration of membranes during aging in plants: evidence for free radical mediation. In: Noodén LD, Leopold AC, eds. Senescence and aging in plants. London, UK: Academic Press Inc. 442-464.

McLeod AR, Long SP. 1999. Free-air carbon dioxide enrichment (FACE) in global change research: a review. Advances in Ecological Research 28: $1-56$.

Menzel A, Fabian P. 1999. Growing season extended in Europe. Nature 397: 659 .

Menzel A, Sparks TH, Estrella N, Koch E, Aasa A, Ahas R, Alm-kübler K, Bissolli P, Braslavská O, Briede A et al. 2006. European phenologi$\mathrm{cal}$ response to climate change matches the warming pattern. Global Change Biology 12: 1-8.

Miglietta F, Peressotti A, Vaccari FP, Zaldei A, DeAngelis P, ScarasciaMugnozza G. 2001. Free-air $\mathrm{CO}_{2}$ enrichment (FACE) of a poplar plantation: the POPFACE fumigation system. New Phytologist 150: 465-476.

Murakami PF, Schaberg PG, Shane JB. 2008. Stem girdling manipulates leaf sugar concentrations and anthocyanin expression in sugar maple trees during autumn. Tree Physiology 28: 1467-1473.

Myneni RB, Keeling CD, Tucker CJ, Asrar G, Nemani RR. 1997. Increased plant growth in the northern high latitudes from 1981 to 1991. Nature 386: 698-702.

Olsen JE, Junttila O, Nilsen J, Eriksson ME, Martinussen I, Olsson O, Sandberg G, Moritz T. 1997. Ecotpic expression of oat phytochrome A in hybrid aspen changes critical daylength for growth and prevents cold acclimatization. Plant Journal 12: 1339-1350.

Park J-Y, Canam T, Kang K-Y, Unda F, Mansfield SD. 2009. Sucrose phosphate synthase expression influences poplar phenology. Tree Physiology 29: 937-946.

Parmesan C, Yohe G. 2003. A globally coherent fingerprint of climate change impacts across natural systems. Nature 421: 37-42.

Peñuelas J, Rutishauser T, Filella I. 2009. Phenology feedbacks on climate change. Science 324: 887-888.

Rae A, Ferris R, Tallis MJ, Taylor G. 2006. Elucidating genomic regions determining enhanced leaf growth and delayed senescence in elevated $\mathrm{CO}_{2}$. Plant, Cell \& Environment 29: 1730-1741.

Rinaldi C, Kohler A, Frey P, Duchaussoy F, Ningre N, Couloux A, Wincker P, Thiec DL, Fluch S, Martin F et al. 2007. Transcript profiling of poplar leaves upon infection with compatible and incompatible strains of the foliar rust Melampsora larici-populina. Plant Physiology 144: 347-366.

Rogers A, Gibon Y, Stitt M, Morgan PB, Bernacchi CJ, Ort DR, Long SP. 2006. Increased carbon availability at elevated carbon dioxide concentration improves nitrogen assimilation in a legume. Plant, Cell \& Environment 29: 1651-1658.

Ruttink T, Arend M, Morreel K, Storme V, Rombauts S, Fromm J, Bhalerao RP, Boerjan W, Rohdea A. 2007. A molecular timetable for apical bud formation and dormancy induction in Poplar. The Plant Cell 19: $2370-2390$.

Scarascia-Mugnozza G, Calfapietra C, Ceulemans R, Gielen B, Cotrufo MF, De Angelis P, Godbold D, Hoosbeek MR, Kull O, Lukac M et al. 2006. Responses to elevated $\left[\mathrm{CO}_{2}\right]$ of a short rotation, multispecies poplar plantation: the POPFACE/EUROFACE experiment. In: Nösberger J, Long SP, Norby RJ, Stitt M, Hendrey GR, Blum H, eds. Ecological studies, Vol. 187. Managed ecosystems and $\mathrm{CO}_{2}$ Case studies, processes and perspectives. Berlin Heidelberg, Germany: Springer-Verlag, 173-195.

Schaberg PG, Murakami PF, Turner MR, Heitz HK, Hawley GJ. 2008. Association of red coloration with senescence of sugar maple leaves in autumn. Trees 22: 573-578.

Sigurdsson BD. 2001. Elevated $\mathrm{CO}_{2}$ and nutrient status modified leaf phenology and growth rhythm of young Populus trichocarpa trees in a 3-year field study. Trees-Structure and Function 15: 403-413.
Sjödin A, Street NR, Sandberg G, Gustafsson P, Jansson S. 2009. The Populus Genome Integrative Explorer (PopGenIE): a new resource for exploring the Populus genome. New Phytologist 182: 1013-1025.

Smyth GK. 2004. Linear models and empirical Bayes methods for assessing differential expression in microarray experiments. Statistical Applications in Genetics and Molecular Biology 3: No. 1, Article 3.

Solfanelli C, Poggi A, Loreti E, Alpi A, Perata P. 2006. Sucrose-specific induction of the anthocyanin biosynthetic pathway in Arabidopsis. Plant Physiology 140: 637-646.

Street NR, Skogström O, Sjödin A, Tucker J, Rodríguez-Ascosta M, Nilsson P, Jansson S, Taylor G. 2006. The genetics and genomics of the drought response in Populus. Plant Journal 48: 321-341.

Taylor G. 2002. Populus. Arabidopsis for forestry. Do we need a model tree? Annals of Botany 90: 681-689.

Taylor G, Street NR, Tricker PJ, Sjodin A, Graham L, Skogstrom O, Calfapietra C, Scarascia-Mugnozza G, Jansson S. 2005. The transcriptome of Populus in elevated $\mathrm{CO}_{2}$. New Phytologist 167: 143-154.

Taylor G, Tallis MJ, Giardina CP, Percy KE, Miglietta F, Gupta PS, Gioli B, Calfapietra C, Gielen B, Kubiske ME et al. 2008. Future atmospheric $\mathrm{CO}_{2}$ leads to delayed autumnal senescence in Populus over two continents. Global Change Biology 14: 264-275.

Teng S, Keurentjes J, Bentsink L, Koornneef M, Smeekens S. 2005. Sucrose-specific induction of anthocyanin biosynthesis in Arabidopsis requires the MYB75/PAP1 gene. Plant Physiology 139: 1840-1852.

Thimm O, Bläsing O, Gibon Y, Nagel A, Meyer S, Krüger P, Selbig J, Müller L, Rhee SYMS. 2004. MAPMAN: a user-driven tool to display genomics data sets onto diagrams of metabolic pathways and other biological processes. Plant Journal 37: 914-939.

Tricker PJ, Trewin H, Kull O, Clarkson GJJ, Eensalu E, Tallis MJ, Colella A, Doncaster CP, Sabatti M, Taylor G. 2005. Stomatal conductance and not stomatal density determines the long-term reduction in leaf transpiration of poplar in elevated $\mathrm{CO}_{2}$. Oecologia 143: 652-660.

Tsai C-J, Harding SA, Tschaplinski TJ, Lindroth RL, Yuan Y. 2006. Genome-wide analysis of the structural genes regulating defense phenylpropanoid metabolism in Populus. New Phytologist 172: 47-62.

Tuskan GA, Difazio S, Jansson S, Bohlmann J, Grigoriev I, Hellsten U, Putnam N, Ralph S, Rombauts S, Salamov A et al. 2006. The genome of black cottonwood, Populus trichocarpa (Torr. \& Gray). Science 313: 1596-1604

Wingler A, Mares M, Pourtau N. 2004. Spatial patterns and metabolic regulation of photosynthetic parameters during leaf senescence. New Phytologist 161: 781-789.

Wingler A, Purdy S, MacLean JA, Pourtau N. 2006. The role of sugars in integrating environmental signals during the regulation of leaf senescence. Journal of Experimental Botany 57: 391-399.

Zhou L, Tucker CJ, Kaufmann RK, Slayback D, Shabanov NV, Myneni RB. 2001. Variations in northern vegetation activity infrerred from satellite data of vegetation index during 1981 to 1999 . Journal of Geophysical Research 106: 20069-20083.

\section{Supporting Information}

Additional supporting information may be found in the online version of this article.

Methods S1 Leaf sampling at the POP/EUROFACE site.

Methods S2 Sampling canopy scale spectral reflectance.

Methods S3 Pre-hybridization, hybridization and scanning of microarrays and raw data normalization. 
Methods S4 The real-time quantitative PCR (qPCR) protocol.

Fig. S1 Leaf glucose and fructose content during senescence.

Fig. S2 A comparison between the expression ratios of selected genes determined using the microarray data and real-time quantitative PCR (RT-qPCR) data.

Table S1 Expression and annotation details of the 13 expressed sequence tags (ESTs) representing significantly up-regulated ( $\geq+3 \quad B$-value and $\geq$ twofold) genes in elevated $\mathrm{CO}_{2}$ on 18 October 2004

Table S2 Expression and annotation details of the 38 expressed sequence tags (ESTs) significantly down-regulated $(\geq+3 B$-value and $\geq$ twofold $)$ genes in elevated $\mathrm{CO}_{2}$ on 18 October 2004

Table S3 Expression and annotation details used for Fig. 3(b)

Table S4 Expression and annotation details of the 75 expressed sequence tags (ESTs) representing significantly up-regulated genes during senescence in elevated $\mathrm{CO}_{2}(18$ October/31 August 2004)
Table S5 Expression and annotation details of the 67 expressed sequence tags (ESTs) representing significantly down-regulated genes during senescence in elevated $\mathrm{CO}_{2}$ (18 October/31 August 2004).

Table S6 Expression and annotation details of the 254 expressed sequence tags (ESTs) representing significantly up-regulated genes during senescence in ambient $\mathrm{CO}_{2}(18$ October/31 August 2004)

Table S7 Expression and annotation details of the 286 expressed sequence tags (ESTs) representing significantly down-regulated genes during senescence in ambient $\mathrm{CO}_{2}$ (18 October/31 August 2004)

Table S8 Expression and annotation details of the expressed sequence tags (ESTs) representing genes classed as significantly up-regulated and in common between this study and the study of Andersson et al. (2004)

Table S9 Expression and annotation details used for Fig. 5(a)

Please note: Wiley-Blackwell are not responsible for the content or functionality of any supporting information supplied by the authors. Any queries (other than missing material) should be directed to the New Phytologist Central Office.

\section{About New Phytologist}

- New Phytologist is owned by a non-profit-making charitable trust dedicated to the promotion of plant science, facilitating projects from symposia to open access for our Tansley reviews. Complete information is available at www.newphytologist.org.

- Regular papers, Letters, Research reviews, Rapid reports and both Modelling/Theory and Methods papers are encouraged We are committed to rapid processing, from online submission through to publication 'as-ready' via Early View - our average submission to decision time is just 29 days. Online-only colour is free, and essential print colour costs will be met if necessary. We also provide 25 offprints as well as a PDF for each article.

- For online summaries and ToC alerts, go to the website and click on 'Journal online'. You can take out a personal subscription to the journal for a fraction of the institutional price. Rates start at $\$ 151$ in Europe/\$279 in the USA \& Canada for the online edition (click on 'Subscribe' at the website).

- If you have any questions, do get in touch with Central Office (newphytol@lancaster.ac.uk; tel +44 1524 594691) or, for a local contact in North America, the US Office (newphytol@ornl.gov; tel +1 865576 5261). 